\title{
SOLUSI NUMERIK MODEL REAKSI-DIFUSI (TURING) DENGAN METODE BEDA HINGGA IMPLISIT
}

\author{
${ }^{1}$ Junik Rahayu, ${ }^{2}$ Usman Pagalay, dan ${ }^{3}$ Ari Kusumastuti \\ 1,2,3Jurusan Matematika UIN Maulana Malik Ibrahim Malang \\ e-mail: rahayujunik@yahoo.com
}

\begin{abstract}
ABSTRAK
Alan Turing (1952) mengemukakan bahwa sistem interaksi bahan kimia dipengaruhi oleh difusi yang tidak stabil yang kemudian berkembang menjadi pola spasial. Hasil dari penelitian ini disebut dengan model reaksi-difusi (Turing).

Pada umumnya model difusi mempunyai difusifitas berupa konstanta. Barras dkk. (2006) mengganti mekanisme Murray (2003) dalam menganalisis model ini, sehingga terbentuklah model dengan rasio pertumbuhan domain yang tumbuh secara eksponensial sebagai difusifitasnya. Hal inilah yang membuat model ini lebih menarik dibandingkan dengan model difusi yang lain.

Berbagai model matematika dipastikan mempunyai solusi, begitu juga dengan model ini. Paper ini membahas penyelesaian numerik pada contoh model. Digunakan metode beda hingga implisit sebagai metode dasar menyelesaikan model. Dalam model terdapat dua konsentrasi yang bereaksi untuk mencapai suatu kesetimbangan. Dari konsentrasi ini akan diperiksa keterikatan pada pertumbuhan domain dengan adanya dinamika gangguan kecil serta pengaruh pertumbuhan domain terhadap penyelesaian numerik model. Dari penyelesaian numerik diperoleh bahwa pertumbuhan domain mempengaruhi dua konsentrasi dalam model dan penyelesaian numerik.
\end{abstract}

Kata kunci: Metode Beda Hingga Implisit, Model Reaksi-Difusi (Turing), Pertumbuhan Domain.

\section{ABSTRACT}

Alan Turing (1952) telling that chemicals interaction system influenced by unstable diffusion which later; then round into pattern of spasial. Result of from this research is referred as with of reaction-diffusion (Turing) model's.

In general diffusion model's have coeficient diffuson in the form of constanta. Barras et. al (2006) changing mechanism of Murray (2003) in analysing this model, is so that formed by model with domain growth ratio which grow by eksponensial as its. This matter make this model more is interesting compared to other diffusion model.

Various mathematics model ascertained to have solution, so also with this model. This Paper study the solving of numeric at model of example.Used by different method till implisit as basic method finish model. In model there are two concentration reacting to reach an is balance. Than this concentration will be checked by binding at domain growth with existence of small trouble dynamics and also influence of domain growth to solving of model numerik. From solving of numeric obtained that domain growth influence two concentration in model and numerical solution.

Keywords: Reaction-Diffusion (Turing) Model's, Finite difference methods, Implicit Scheme,Domain Growth Rate.

\section{PENDAHULUAN}

Alan Turing (1952) mengemukakan bahwa sistem interaksi bahan kimia dipengaruhi oleh difusi yang tidak stabil yang kemudian berkembang menjadi pola spasial. Dalam era integrasi biologi, model hasil penelitian Alan Turing merupakan salah satu contoh pertama bagaimana mengintegrasikan proses sederhana yang dapat memberikan hasil yang kompleks, dalam hal ini, kombinasi dari proses penyetabilan yang menghasilkan sistem yang tidak stabil. Pada model tersebut, diasumsikan bahwa sel tidak bergerak tetapi hanya menanggapi pembedaan isyarat kimia. Hasil dari penelitian ini disebut dengan model reaksi-difusi (Turing).

Barras dkk (2006) mengganti mekanisme model Murray (2003) dalam menganalisis model ini dengan domain pertumbuhan menggunakan kinetika Schnakenberg, yang timbul dari suatu penerapan hukum aksi massa untuk skema trimolecular. Menurut Barras dkk (2006) model terdiri dari 2 persamaan diferensial parsial dan 1 persamaan diferensial biasa, sehingga membentuk sistem. Dalam jurnalnya Barras dkk (2006) mengungkap bahwa proses transisi dalam 
model mencapai puncak didorong oleh pertumbuhan domain sehingga menghasilkan urutan pola.

Model matematis yang kompleks seperti model ini, sukar mendapatkan solusinya dengan solusi analitis. Walaupun metode numerik dalam pencarian solusi dari suatu sistem juga jarang digunakan akhir-akhir ini, akan tetapi metode ini merupakan alternatif dalam menyelesaikan persoalan matematik. Metode ini dapat digunakan untuk mendekati solusi secara eksak.

Salah satu metode numerik untuk menyelesaikan persamaan diferensial parsial seperti model ini adalah metode beda hingga. Dalam metode beda hingga terdapat bermacam skema, salah satunya skema implisit yang stabil tanpa syarat.

\section{KAJIAN TEORI}

\section{A. Analisis Persamaan Diferensial Parsial Pada Model Reaksi-Difusi (Turing)}

Suatu persamaan yang di dalamnya terdapat turunan parsial dan terdapat dua atau lebih variabel bebas maka persamaan tersebut disebut persamaan diferensial parsial (partial differential equation/pde) (Ayres, 1992).

Bentuk umum persamaan diferensial parsial linear orde 2 dalam 2 variabel bebas adalah:

$$
A f_{x x}+B f_{x y}+C f_{y y}+D f_{x}+E f_{y}+F f=G
$$

Menurut Sasongko (2010) persamaan di atas dapat dinyatakan sebagai kondisi-kondisi berikut:

1. Apabila koefisien $A, B, C, D, E, F, G$ adalah konstanta atau fungsi yang terdiri dari variabel bebas saja, maka persamaan tersebut disebut linier.

2. Apabila koefisien $A, B, C, D, E, F, G$ adalah fungsi dari variabel tak bebas dan atau merupakan turunan dengan orde yang lebih rendah daripada persamaan diferensialnya $\left(\frac{\partial u}{\partial x}, \frac{\partial u}{\partial t}\right)$, maka persamaan tersebut disebut kuasilinier.

3. Apabila koefisien $A, B, C, D, E, F, G$ adalah fungsi dengan orde turunan yang sama dengan orde persamaan diferensialnya $\left(\frac{\partial^{2} u}{\partial x^{2}}, \frac{\partial^{2} u}{\partial t^{2}}, \frac{\partial^{2} u}{\partial x \partial t}\right)$

maka persamaan tersebut disebut persamaan non-linier.

Tipe dari persamaan diferensial orde dua ditentukan oleh determinan $(D)$ jika:
a. $\quad D=B^{2}-4 A C<0$, maka bertipe Eliptik.
b. $D=B^{2}-4 A C=0$, maka bertipe Parabolik.
c. $D=B^{2}-4 A C>0$, maka bertipe Hiperbolik.

Model Turing menurut Barras dkk (2006) berbentuk:

$$
\left\{\begin{array}{l}
\frac{\partial u}{\partial t}=\frac{1}{L^{2}} \frac{\partial^{2} u}{\partial x^{2}}+a-u v^{2}-\rho u \\
\frac{\partial v}{\partial t}=\frac{d}{L^{2}} \frac{\partial^{2} v}{\partial x^{2}}+b+u v^{2}-v-\rho v \\
\frac{d L}{d t}=\rho L
\end{array}\right.
$$

Dengan mengganti persamaan $\frac{d L}{d t}=\rho L$ menjadi persamaan diferensial biasa, diasumsikan $L(0)=$ 1, maka model menjadi bentuk berikut:

$$
\left\{\begin{array}{l}
u_{t}=\frac{1}{L(t)^{2}} u_{x x}+a-u v^{2}-\rho u \\
v_{t}=\frac{d}{L(t)^{2}} v_{x x}+b+u v^{2}-v-\rho v \\
L(t)=e^{\rho t}
\end{array}\right.
$$

Dari derinisi yang telah diuraikan di atas, maka model dapat diklasifikasikan menjadi persamaan diferensial parsial kuasilinier orde dua tipe Parabolik.

Solusi model adalah fungsi $u(x, t)$ dan $v(x, t)$ yang memenuhi persamaan di atas. Solusi tersebut merupakan solusi umum, sehingga diperlukan subtitusi kondisi batas dan kondisi awal agar didapatkan solusi khusus. Kondisi batas yang digunakan pada model adalah Dirichlet Boundary Conditions. Untuk interval $0 \leq t \leq 0.002$ dan $0 \leq x \leq 1$. Nilai batas $u(0, t)=0.9$; $u(0,0.002)=0.9 ; \quad v(0, t)=1 \quad$ dan $\quad v(0,0.002)=1$ untuk semua $t$. Sedangkan kondisi awal yang digunakan untuk model adalah $L(t)$ yang dirumuskan sebagai berikut:

$$
u(x, 0)=v(x, 0)=L(t)=e^{\rho t}
$$

Persamaan tersebut akan digunakan untuk membuat iterasi numerik pada pembahasan.

\section{B. Analisis Model Reaksi-Difusi (Turing)}

Pemodelan Matematika mengenai model reaksi-difusi dikemukakan oleh Alan Turing (1952) yang mengidentifikasi perkembangan embrio menjadi dewasa. Dalam penelitiannya Alan Turing mengasumsikan bahwa sistem interaksi bahan kimia dipengaruhi oleh difusi yang tidak stabil yang kemudian berkembang menjadi pola spasial.

Barras dkk (2006) mengganti mekanisme model Murray (2003) dalam menganalisis model 
dengan domain pertumbuhan menggunakan kinetika Schnakenberg, yang timbul dari suatu penerapan hukum aksi massa untuk skema trimolecular, sehingga terbentuklah model. Pada model diasumsikan proses difusi dalam kasus pertumbuhan domain yang tumbuh secara eksponensial.

Selanjutnya Brownian motion untuk persamaan $u_{t}=\frac{1}{L(t)^{2}} u_{x x}+a-u v^{2}-\rho u$ dapat dituliskan sebagai,

$$
u_{t}-\frac{1}{L(t)^{2}} u_{x x}-a+u v^{2}+\rho u=0
$$

Menurut Zauderer (1998:2-5), untuk menyelesaikan persamaan $u(x, t)$ di atas, digunakan asumsi-asumsi sebagai berikut:

1. Ekspektasi dari variabel acak $x$ atau disebut juga sebagai lokasi perpindahan partikel dalam gelombang yang didefinisikan:

$$
E(x)=x=(p-q) \delta
$$

dengan $C$ adalah kecepatan difusi, dan dalam masalah ini kecepatan difusi dianggap sama dengan nol.

2. Varian dari suatu variabel acak $x$ atau disebut juga dengan besarnya perpindahan yang terjadi dari suatu proses difusi, didefinisikan sebagai berikut:

$$
V(x)=4 p \delta^{2}
$$

dengan $D$ adalah konstanta atau koefisien difusi yang dalam hal ini diasumsikan besarnya sama dengan $2 / L(t)^{2}$.

3. Asumsi dasar difusi yang digunakan adalah $u(x, t)$ yang merupakan distribusi peluang. Dimana distribusi peluang dari suatu partikel pada langkah $x$ dan pada waktu yang ke $t+\tau$ sama dengan peluang ketika berada pada titik $x-\delta$ pada waktu $t$ dikalikan dengan peluang perpindahan partikel ke arah kanan $(p)$ pada suatu langkah ditambah dengan peluang partikel pada saat berada di titik $x+\delta$ pada waktu $t$ dikalikan dengan probabilitas perpindahan ke arah kiri $(q)$ pada suatu langkah, dimana $p+q=1$, yang dapat dituliskan dalam bentuk berikut:

$$
\begin{aligned}
u(x, t+\tau)=p u & (x-\delta, t) \\
& +q u(x+\delta, t)
\end{aligned}
$$

dimana $\tau$ merupakan partisi waktu.

4. $\quad p$ adalah peluang perpindahan partikel ke arah kanan, sedangkan $q$ adalah peluang perpindahan partikel ke arah kiri, dimana $p, q \in R$.
Untuk menyelesaikan brownian motion persamaan $u(x, t)$ di atas, digunakan deret Taylor sebagai berikut:

a. Untuk $u(x, t+\tau)=u(x, t)+\tau u_{t}(x, t)$.

b. Untuk $u(x-\delta, t)=u(x, t)-\delta u_{x}(x, t)+$ $\frac{1}{2} \delta^{2} u_{x x}(x, t)$.

c. Untuk $u(x+\delta, t)=u(x, t)+\delta u_{x}(x, t)+$ $\frac{1}{2} \delta^{2} u_{x x}(x, t)$

sedangkan untuk persamaan $v_{t}=\frac{d}{L(t)^{2}} v_{x x}+b+$ $u v^{2}-v-\rho v$ dapat ditulis sebagai:

$$
v_{t}-\frac{d}{L(t)^{2}} v_{x x}-b-u v^{2}+v+\rho v=0 .
$$

Menurut Zauderer (1998:2-5), untuk menyelesaikan persamaan $v(x, t)$ di atas, digunakan asumsi-asumsi sebagai berikut:

1. Ekspektasi dari variabel acak $x$ atau disebut juga sebagai lokasi perpindahan partikel dalam gelombang yang didefinisikan:

$E(x)=x=(p-q) \delta$,

dengan $C$ adalah kecepatan difusi, dan dalam masalah ini kecepatan difusi dianggap sama dengan nol

2. Varian dari suatu variabel acak $x$ atau disebut juga dengan besarnya perpindahan yang terjadi dari suatu proses difusi, didefinisikan sebagai berikut:

$$
V(x)=4 p \delta^{2},
$$

dengan $D$ adalah konstanta atau koefisien difusi yang dalam hal ini diasumsikan besarnya sama dengan $2 d / L(t)^{2}$.

3. Asumsi dasar difusi yang digunakan adalah $v(x, t)$ yang merupakan distribusi peluang. Dimana distribusi peluang dari suatu partikel pada langkah $x$ dan pada waktu yang ke $t+\tau$ sama dengan peluang ketika berada pada titik $x-\delta$ pada waktu $t$ dikalikan dengan peluang perpindahan partikel ke arah kanan $(p)$ pada suatu langkah ditambah dengan peluang partikel pada saat berada di titik $x+\delta$ pada waktu $t$ dikalikan dengan probabilitas perpindahan ke arah kiri $(q)$ pada suatu langkah, dimana $p+q=1$, yang dapat dituliskan dalam bentuk berikut:

$$
\begin{aligned}
v(x, t+\tau)=p v & (x-\delta, t) \\
& +q v(x+\delta, t)
\end{aligned}
$$

dimana $\tau$ merupakan partisi waktu.

4. $\quad p$ adalah peluang perpindahan partikel ke arah kanan, sedangkan $q$ adalah peluang 
perpindahan partikel ke arah kiri, dimana $p, q \in R$.

Untuk menyelesaikan brownian motion persamaan $v(x, t)$ di atas, digunakan deret Taylor sebagai berikut:

a. Untuk $v(x, t+\tau)=v(x, t)+\tau v_{t}(x, t)$.

b. Untuk $v(x-\delta, t)=v(x, t)-\delta u_{x}(x, t)+$ $\frac{1}{2} \delta^{2} v_{x x}(x, t)$.

c. Untuk $v(x+\delta, t)=u(x, t)+\delta v_{x}(x, t)+$ $\frac{1}{2} \delta^{2} v_{x x}(x, t)$.

Nilai parameter, kondisi awal dan kondisi batas mengacu pada keterangan Barras dkk (2006) dengan $\rho$ merupakan rasio domain pertumbuhan, $-\rho u$ dan $-\rho v$ adalah dilution effect, energi kinetik $a=0.9$ dan $b=0.1$ dan koefisien difusi $d=0.06$. Beberapa nilai $\rho$ yang sesuai dengan keterangan Barras dkk (2006) yaitu $\rho=0.001, \rho=0.05$ dan $\rho=0.01$.

\section{Metode Beda Hingga Skema Implisit untuk Model Reaksi-Difusi (Turing)}

Dibentuk skema beda hingga untuk turunan parsial fungsi $u$ dan $v$ yang terdiri dari dua variabel bebas $x$ dan $t$. Berikut merupakan deret Taylor:(Causaon dan Mingham, 2010)

$$
\begin{aligned}
u\left(x_{0}+\Delta x, t\right)= & u\left(x_{0}, t\right)+\frac{\Delta x^{2}}{2 !} u_{x x}\left(x_{0}, t\right)+\ldots \\
& +\frac{\Delta x^{n-1}}{(n-1) !} u_{(n-1)}\left(x_{0}, t\right)+O\left(\Delta x^{n}\right),
\end{aligned}
$$

Dalam skema implisit, untuk menghitung variabel di suatu titik perlu dibuat suatu sistem persamaan yang mengandung variabel di titik tersebut dan titik-titik sekitarnya pada waktu yang sama (Triatmodjo, 2002). Berikut merupakan langkah iterasi pada skema implisit:

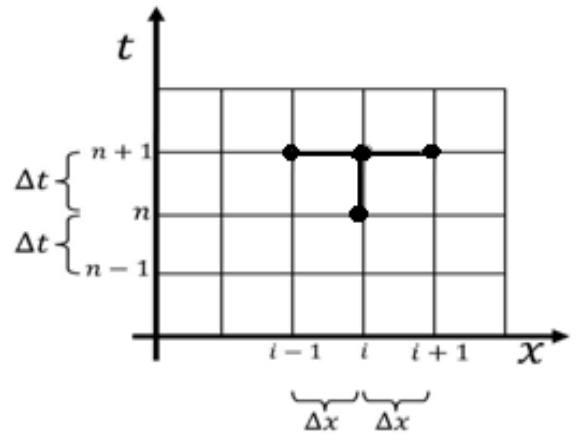

Gambar 1. Gambar Skema Implisit

Gambar skema di atas digunakan untuk menghitung turunan petama dan kedua model reaksi-difusi (Turing).

\section{PEMBAHASAN}

\section{A. Metode Beda Hingga Skema Implisit Model Reaksi-Difusi (Turing)}

(Turing):

Berikut merupakan model reaksi-difusi

$$
\left\{\begin{array}{c}
u_{t}=\frac{1}{L(t)^{2}} u_{x x}+a-u v^{2}-\rho u \\
v_{t}=\frac{d}{L(t)^{2}} v_{x x}+b+u v^{2}-v-\rho v \\
L(t)=e^{\rho t}
\end{array}\right.
$$

pada persamaan $u_{t}=\frac{1}{L(t)^{2}} u_{x x}+a-u v^{2}-\rho u$, maka dapat dinyatakan bentuk diskritnya sebagai berikut:

$$
\begin{array}{r}
-\alpha u_{i-1}^{n+1}+(1+2 \alpha) u_{i}^{n+1}-\alpha u_{i+1}^{n+1} \\
=u_{i}^{n}+\Delta t\left(a-u_{i}^{n}\left(v_{i}^{n}\right)^{2}-\rho u_{i}^{n}\right.
\end{array}
$$

dengan $\alpha=\frac{\Delta t}{L(t)^{2} \Delta x^{2}}$. Adapun stensilnya dapat digambarkan sebagai berikut:

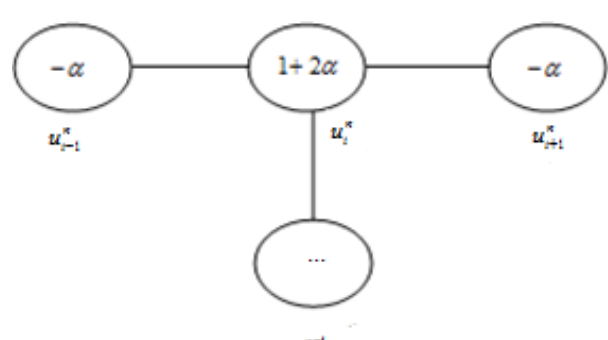

Gambar 2. Stensil untuk Persamaan $u(x, t)$

Selanjutnya pada persamaan $v_{t}=\frac{d}{L(t)^{2}} v_{x x}+b+u v^{2}-v-\rho v$, maka dapat dinyatakan bentuk diskritnya sebagai berikut:

$$
-\beta v_{i-1}^{n+1}+(1+2 \beta) v_{i}^{n+1}-\beta v_{i+1}^{n+1}=v_{i}^{n}+\Delta t\left(b+u_{i}^{n} v_{i}^{n^{2}}-v_{i}^{n}-\rho v_{i}^{n}\right) .
$$

dengan

$$
\beta=d \frac{\Delta t}{L(t)^{2} \Delta x^{2}}=d \alpha .
$$

Stensilnya dapat di lihat pada gambar 3 berikut ini.

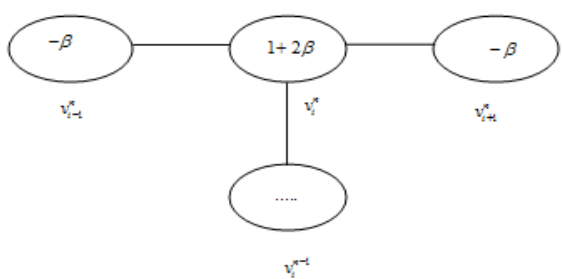

Gambar 3. Stensil untuk Persamaan $v(x, t)$

Jaringan titik hitung beda hingga implisit untuk model pada daerah $x_{0} \leq x \leq R$ dan $t_{0} \leq$ 
$t \leq T$ adalah sebagai berikut dapat dilihat pada gambar 4 .

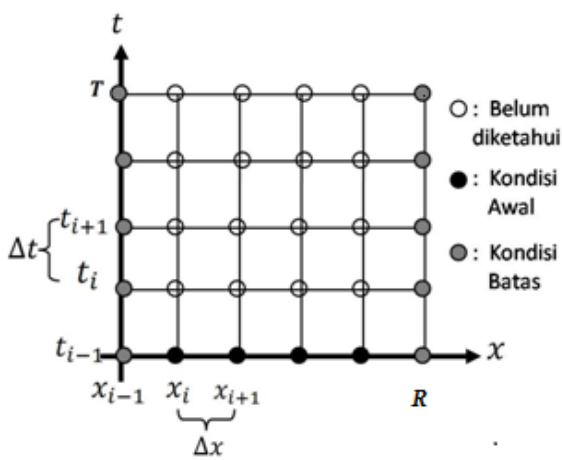

Gambar 4. Jaringan Titik Hitung Beda Hingga Implisit untuk Model.

Digunakan kondisi awal sebagai berikut:

$$
\begin{aligned}
& u(x, 0)=0.9+\text { bilangan random } \\
& v(x, 0)=1+\text { bilangan random }
\end{aligned}
$$

Setelah didapatkan nilai awal dan nilai batas, iterasi dilakukan pada hasil diskritisasi dengan sesuai jaringan titik hitung pada Gambar 4.

\section{B. Penyelesaian Numerik Model Reaksi- Difusi (Turing)}

Diselesaikan contoh model reaksi-difusi (Turing) pada daerah batas $0<x<1$ dan $0<t<$ 0.002 , rasio pertumbuhan domain $\rho=0.001$, energi kinetik $a=0.9$ dan $a=0.1$ serta rasio koefisien difusi $d=0.06$ sehingga model dapat dituliskan sebagai berikut:

$\left\{\begin{array}{c}u_{t}=\frac{1}{L(t)^{2}} u_{x x}+0.9-u v^{2}-0.001 u \\ v_{t}=\frac{0.06}{L(t)^{2}} v_{x x}+0.1+u v^{2}-v-0.001 v \\ L(t)=e^{\alpha t}\end{array}\right.$

Dipilih nilai $\Delta t=0.00002$ dan $\Delta x=0.01$.

Selanjutnya dilakukan iterasi dengan kondisi batas sebagai berikut:

$$
\begin{aligned}
& u\left(x_{0}, t\right)=u(0, t)=0.9, u(R, t)=u(1, t)=0.9 \\
& v\left(x_{0}, t\right)=v(0, t)=1, v(R, t)=v(1, t)=1
\end{aligned}
$$

sehingga diperoleh:

$u_{i}^{n}=0.9, \forall n=0,1,2, \ldots, 100, \forall i=0,1,2, \ldots, 100$

$v_{i}^{n}=1, \quad \forall n=0,1,2, \ldots, 100, \forall i=0,1,2, \ldots, 100$

Langkah berikutnya yaitu dilakukan iterasi kondisi awal sebagai berikut:

$u_{i}^{n}=f\left(t_{i}\right)=0.9+$ bilangan random,$\quad \forall n=0$, $\forall i=1,2, \ldots, 99$.

$v_{i}^{n}=g\left(t_{i}\right)=1+$ bilangan random, $\quad \forall n=0$, $\forall i=1,2, \ldots, 99$.
Setelah didapatkan nilai awal dan nilai batas, iterasi dilakukan pada hasil diskritisasi sesuai jaringan titik hitung pada Gambar 5.

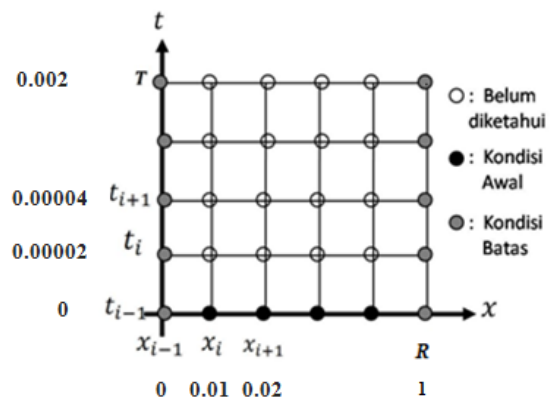

Gambar 5. Jaringan Titik Hitung Skema Beda Hingga Implisit untuk Model dengan Parameter $x$ dan $t$

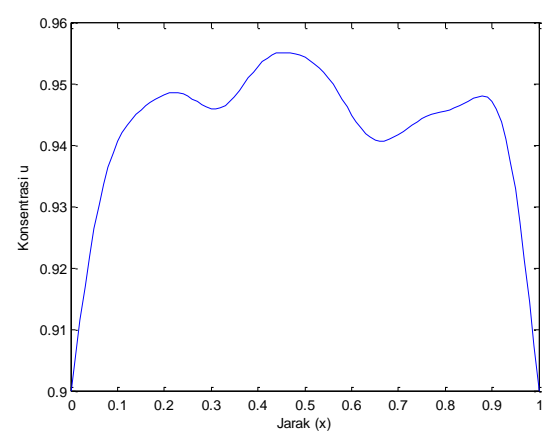

Gambar 6. Grafik Solusi Numerik untuk $u(x, t)$ terhadap Jarak $(x)$ dengan $\rho=0.001$.

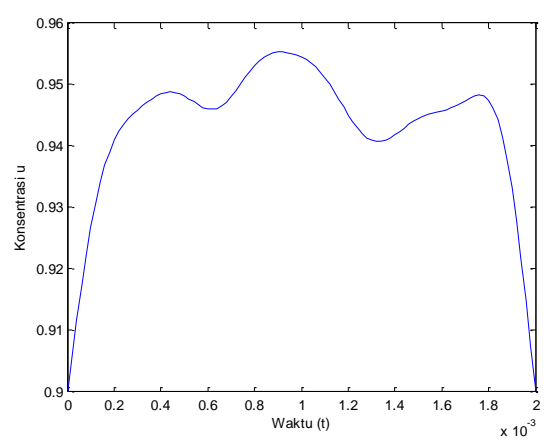

Gambar 7. Grafik Solusi Numerik untuk $u(x, t)$ terhadap waktu $(t)$ dengan $\rho=0.001$.

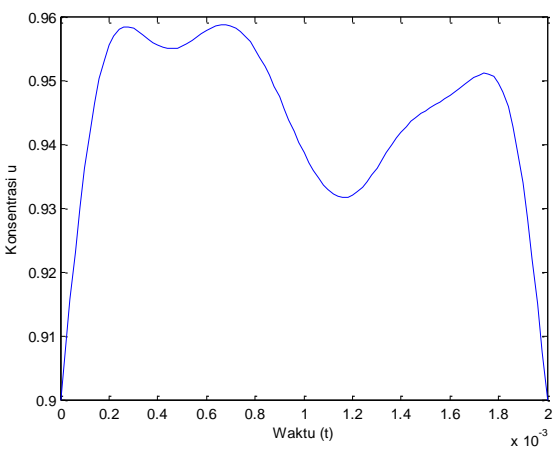

Gambar 8. Grafik Solusi Numerik untuk $v(x, t)$ terhadap Jarak $(x)$ dengan $\rho=0.001$. 


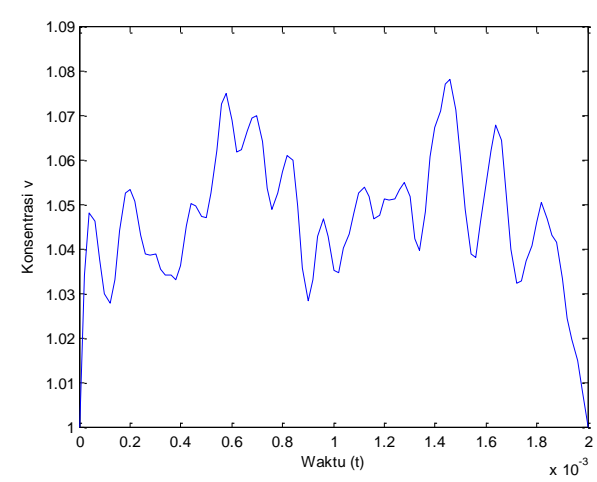

Gambar 9. Grafik Solusi Numerik untuk $v(x, t)$ terhadap Jarak $(x)$ dengan $\rho=0.001$.

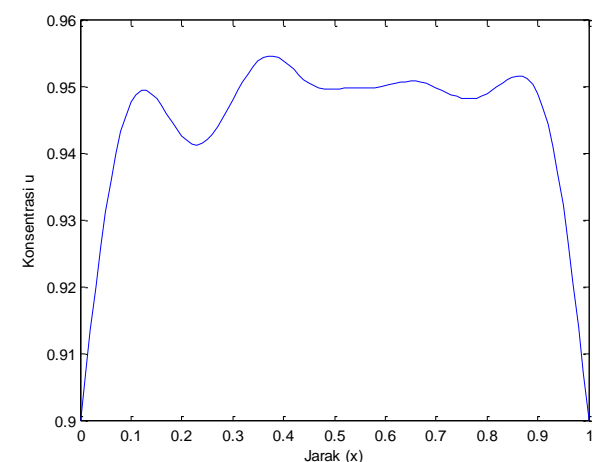

Gambar 10. Grafik Solusi Numerik untuk $u(x, t)$ terhadap Jarak $(x)$ dengan $\rho=0.05$.

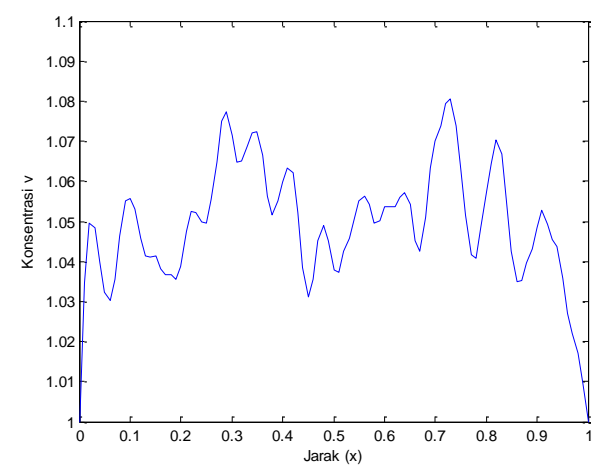

Gambar 11. Grafik Solusi Numerik untuk $u(x, t)$ terhadap Waktu $(t)$ dengan $\rho=0.05$.

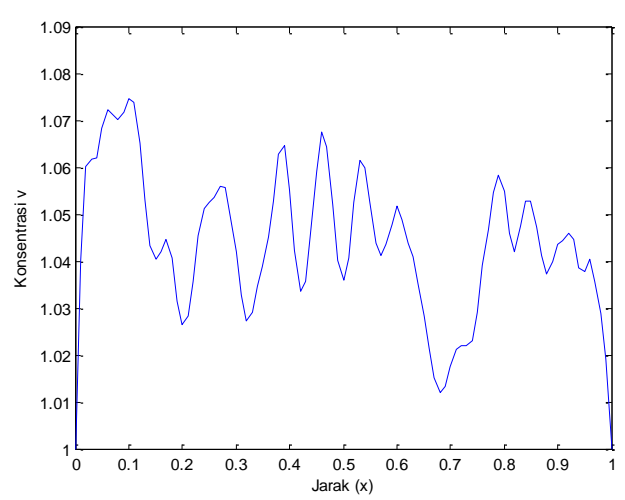

Gambar 12. Grafik Solusi Numerik untuk $v(x, t)$ terhadap Jarak $(x)$ dengan $\rho=0.05$

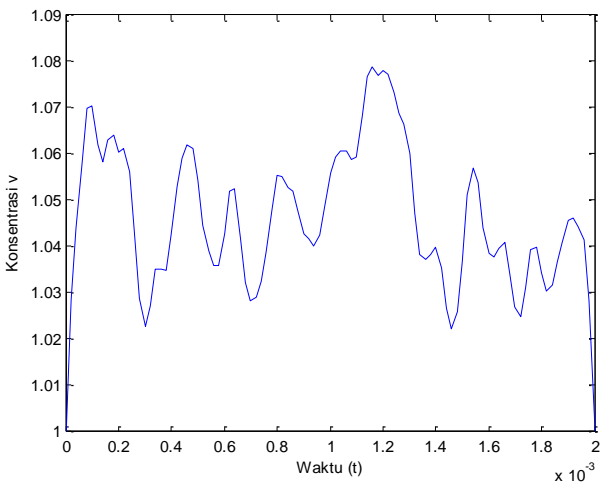

Gambar 13. Grafik Solusi Numerik untuk $v(x, t)$ terhadap Waktu $(t)$ dengan $\rho=0.05$.

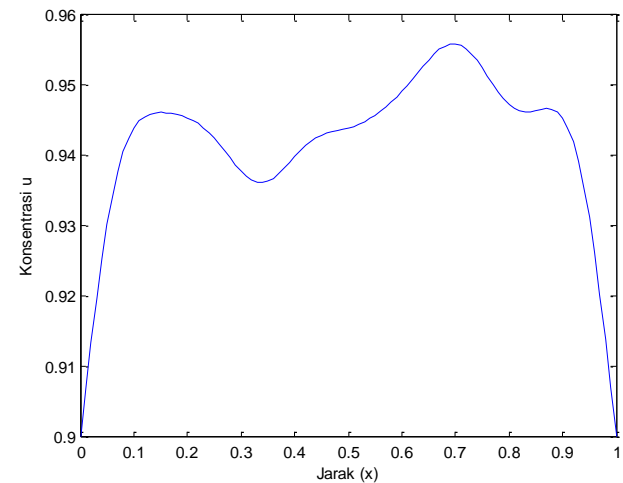

Gambar 14. Grafik Solusi Numerik untuk $u(x, t)$ terhadap Jarak $(x)$ dengan $\rho=0.01$.

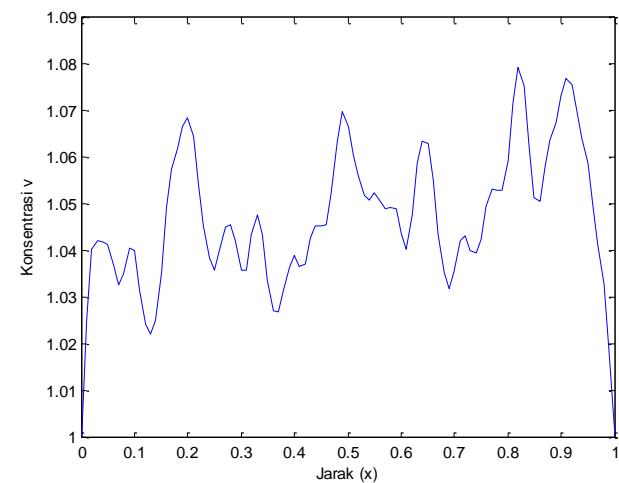

Gambar 15. Grafik Solusi Numerik untuk $u(x, t)$ terhadap Waktu $(t)$ dengan $\rho=0.01$.

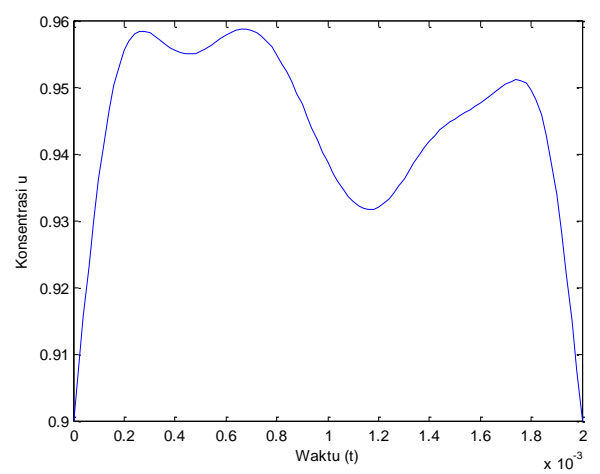

Gambar 16. Grafik Solusi Numerik untuk $v(x, t)$ terhadap Jarak $(x)$ dengan $\rho=0.01$. 


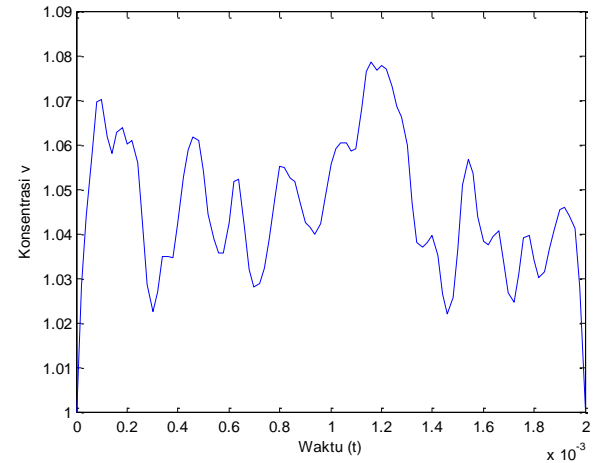

Gambar 17. Grafik Solusi Numerik untuk $v(x, t)$ terhadap Waktu $(t)$ dengan $\rho=0.01$.

\section{Interpretasi Penyelesaian Numerik Model Reaksi-Difusi (Turing)}

Kondisi batas yang digunakan dalam bahasan ini adalah

$$
\begin{aligned}
& u\left(x_{0}, t\right)=u(0, t)=0.9, u(R, t)=u(1, t)=0.9 . \\
& v\left(x_{0}, t\right)=v(0, t)=1, v(R, t)=v(1, t)=1 .
\end{aligned}
$$

hal tersebut diinterpretasi bahwa $x_{0}$ dan $R$ merupakan batas domain yang diselesaikan sehingga efek dilusi sebelum $x_{0}$ dan $R$ diabaikan. Nilai batas 0.9 dapat dimaknai bahwa energi kinetik non-dimensional pada titik $x_{0}=0$ sebesar 0.9 dan nilai batas 1 dapat dimaknai bahwa energi kinetik non-dimensional pada titik $x_{n}=R$ sebesar 1 pada masing-masing konsentrasi untuk semua waktu $t$. Dengan adanya kondisi batas yang diberikan, maka dapat memberikan batasan daerah yang akan diselesaikan.

Parameter-parameter yang digunakan di dalam model yaitu $\rho$ merupakan rasio pertumbuhan domain, $-\rho u$ dan $-\rho v$ adalah dilution effect, energi kinetik pada $a=0.9$ dan $b=0.1$ dan koefisien difusi $d=0.06$.

Kondisi awal yang digunakan dalam pembahasan contoh model adalah sebagai berikut:

$$
\begin{aligned}
& u_{i}^{n}=f\left(t_{i}\right)=0,9+\text { bilangan random, } \forall n=0, \forall i=1,2, \ldots, 99 \\
& v_{i}^{n}=g\left(t_{i}\right)=1+\text { bilangan random, } \forall n=0, \forall i=1,2, \ldots, 99
\end{aligned}
$$

Kondisi tersebut dapat dimaknai bahwa energi kinetik non-dimensional pada titik $x_{0}$ pada waktu $t_{i}$ untuk masing-masing konsentrasi dipengaruhi oleh adanya penambahan bilangan random di belakang suatu konstanta.

Dengan membandingkan Gambar 1, 2, 3, 4 , 5 dan 6 dapat diketahui bahwa nilai $\rho$ mempengaruhi perubahan konsentrasi $u(x, t)$ dan $v(x, t)$. Sehingga dapat disimpulkan nilai $\rho$ mempengaruhi penyelesaian numerik pada model reaksi-difusi (Turing).

\section{PENUTUP}

Berdasarkan pembahasan, dapat diperoleh bahwa untuk menyelesaikan model dengan menttransformasikan dalam bentuk skema beda hingga implisit menggunakan beda maju untuk turunan pertama terhadap waktu dan beda simetrik untuk tururnan kedua terhadap ruang, sehingga diperoleh bentuk diskrit model reaksidifusi (Turing) sebagai berikut:

$$
\begin{aligned}
& -\alpha u_{i-1}^{n+1}+(1+2 \alpha) u_{i}^{n+1}-\alpha u_{i+1}^{n+1}=u_{i}^{n}+\Delta t\left(a-u_{i}^{n}\left(v_{i}^{n}\right)^{2}-\rho u_{i}^{n}\right) \\
& -\beta v_{i-1}^{n+1}+(1+2 \beta) v_{i}^{n+1}-\beta v_{i+1}^{n+1}=v_{i}^{n}+\Delta t\left(b+u_{i}^{n} v_{i}^{n^{2}}-v_{i}^{n}-\rho v_{i}^{n}\right) .
\end{aligned}
$$

Selanjutnya dilakukan iterasi dengan parameter, kondisi batas dan kondisi awal pada daerah batas yang telah ditentukan pada hasil diskritisasi di atas. Untuk menghitung solusi numerik digunakan program yang tertera pada Lampiran.

Berdasar hasil perhitungan diperoleh solusi numerik untuk model reaksi-difusi (Turing) berupa matriks ukuran 101x101. Simulasi Gambar, menunjukkan rasio domain pertumbuhan $(\rho)$ mempengaruhi dua konsentrasi pada proses difusi serta mempengaruhi penyelesaian numerik model.

Peneliti lain diharapkan dapat mengembangkan penelitian ini dalam kasus dua dimensi ataupun dengan menurunkan model yang berupa persamaan diferensial parsial menjadi persamaan diferensial biasa sehingga dapat dibandingkan hasilnya dengan penelitian ini.

\section{DAFTAR PUSTAKA}

[1] Ayres, F. 1992. Persamaan Diferensial. Jakarta: Erlangga.

[2] Causon, D.M dan Mingham, C.G.. 2010. Introductory Finite Difference Methods for PDEs. United Kingdom: Ventus Publishing Aps.

[3] Barras, I., Crampin E. J., dan Maini P. K.. 2006. Mode Transitions in a Model ReactionDiffusion System Driven by Domain Growth and noise. Bulletin of Mathematical Biology (2006) 68: 981-995.

[4] Murray, J.D.. 2003. Mathematical Biology 3rd edition in 2 volumes: Spatial Models and Biomedical Applications. New York: Springer.

[5] Sasongko, S. B. 2010. Metode Numerik dengan Scilab. Yogyakarta: C.V Andi Offset. 
[6] Triatmodjo, B. 2002. Metode Numerik. Yogyakarta: Beta Offset.

[7] Turing, A.M.. 1952. The chemical basis of morphogenesis. London: Phil. Trans. R. Soc.

[8] Zauderer, E.. 1998. Partial Differential Equations of Applied Mathematics, Second Edition. New York: John Wiley. 